\title{
Identification of Multiple Phosphoinositide-Linked Receptors on Human SK-N-MC Neuroepithelioma Cells
}

\author{
*Stephen K. Fisher and Rachel E. Landon \\ Neuroscience Laboratory and *Department of Pharmacology, University of Michigan, Ann Arbor, Michigan, U.S.A.
}

\begin{abstract}
The biochemical and pharmacological characteristics of receptor-stimulated phosphoinositide (PPI) hydrolysis in human SK-N-MC neuroepithelioma cells have been examined. Of 11 ligands tested, the addition of four, i.e., norepinephrine, oxotremorine-M, endothelin-1, and ATP, each resulted in an increased release (three- to eightfold) of inositol phosphates from $\left[{ }^{3} \mathrm{H}\right]$ inositol-prelabeled cells. Agonist-stimulated PPI turnover was sustained for at least $30 \mathrm{~min}$ and required the addition of $\mathrm{Ca}^{2+}$ for full effect. An increased release of inositol phosphates could also be elicited by the addition of the $\mathrm{Ca}^{2+}$ ionophore, ionomycin. All four agonists enhanced the release of radiolabeled inositol mono- and bisphosphates, inositol 1,3,4-trisphosphate, and inositol tetrakisphosphate. Increases in inositol 1,4,5-trisphosphate were smaller and only consistently observed in the presence of norepinephrine or oxotremorine-M. Norepinephrine-stimulated PPI turnover was potently inhibited by prazosin, WB4101 , and 5-methylurapidil $\left(K_{\mathrm{i}}<2.5 \mathrm{n} M\right)$, but was relatively insensitive to chloroethylclonidine pretreatment. This pharmacological profile is consistent with the involvement of an $\alpha_{1 \mathrm{~A}}$-receptor subtype. The presence of an $\mathbf{M}_{\mathbf{l}}$ muscarinic cholinergic receptor is also indicated, because pirenzepine
\end{abstract}

blocked oxotremorine-M-stimulated inositol phosphate release $\left(K_{\mathrm{i}}=35 \mathrm{n} M\right)$ with a 30 -fold greater potency than the $\mathbf{M}_{2}$-selective antagonist, AF-DX 116. Of the three endothelins tested, only the addition of endothelin-1 and endothelin-2 promoted PPI hydrolysis, whereas endothelin-3 was essentially inactive. A $P_{2}$ nucleotide receptor of broad agonist specificity is also present on these cells and activates PPI turnover in the absence of a generalized increase in plasma membrane permeability. These results indicate that SK-NMC cells express at least four PPI-linked receptors. Because the functional coupling of three of these receptors, i.e., $\alpha_{1 A^{-}}$ adrenergic, endothelin, and $\mathrm{P}_{2}$ nucleotide, has not been extensively characterized previously in neural tissues, the SK$\mathrm{N}-\mathrm{MC}$ cell line may provide a useful model system for studies of these receptors and their regulation. Key Words: Phosphoinositide hydrolysis-Neuroepithelioma- $\mathbf{M}_{1}$ muscarinic cholinergic receptor $-\alpha_{1 \mathrm{~A}}$-Adrenergic receptor $-\mathbf{P}_{2}$ nucleotide receptor-Endothelin. Fisher S. K. and Landon R. E. Identification of multiple phosphoinositide-linked receptors on human SK-N-MC neuroepithelioma cells. J. Neurochem, 57, 1599-1608 (1991).
The CNS and other neural-related tissues possess a large number of pharmacologically distinct receptors coupled to phosphoinositide (PPI) hydrolysis. Activation of these receptors elicits a phosphodiesteratic breakdown of phosphatidylinositol 4,5-bisphosphate with the concomitant formation of two intracellular second messengers, diacylglycerol and inositol 1,4,5trisphosphate (for review, see Fisher and Agranoff, 1987). Due to the complexity of the nervous system, the use of homogeneous cultured neurotumor cell lines, such as neuroblastomas and astrocytomas, has proved invaluable both in the identification of individual receptor subtypes coupled to PPI turnover and in studies of their regulation. However, although the characterization of several receptor subtypes linked to PPI turnover has been facilitated by this approach, for other functionally linked receptors, few if any suitable neural cell lines are presently available. In the present study, we have investigated the presence of PPI-linked receptors on human SK-N-MC neuroepithelioma cells. Although previously designated as a neuroblastoma (Biedler et al., 1973), this cell line is more appropriately
Received January 10, 1991; revised manuscript received April 4, 1991; accepted April 8, 1991.

Address correspondence and reprint requests to Dr. S. K. Fisher at University of Michigan, Neuroscience Laboratory, $1103 \mathrm{E}$. Huron St., Ann Arbor, MI 48104-1687, U.S.A.

Abbreviations used: $\mathrm{ADP} \beta \mathrm{S}$, adenosine 5'-O-(2-thiodiphosphate); AF-DX 116, 11-[[2-[(diethylamino)methyl]-1-piperidinyl]-acetyl]5,11-dihydro-6H-pyrido[2,3-b][1,4]benzodiazepin-6-one; ATP $\gamma$ S, adenosine 5'-O-(3-thiotriphosphate); Epi, epinephrine; ET, endothelin;
fura-2/AM, pentaacetoxymethyl ester derivative of fura-2; $\mathrm{IP}_{1}, 1-\mathrm{D}-$ myo-inositol monophosphate; $\mathrm{IP}_{2}, 1-\mathrm{D}-m y o$-inositol bisphosphate; $\mathrm{IP}_{3}, 1$-D-myo-inositol trisphosphate; $\mathrm{IP}_{4}, 1$-D-myo-inositol tetrakisphosphate (isomeric positioning of phosphate groups are indicated when appropriate); 2MeSATP, 2-methylthioadenosine 5'-triphosphate; NE, norepinephrine; Oxo-M, oxotremorine-M; PPI, phosphoinositide (phosphatidylinositol, phosphatidylinositol 4-phosphate, and phosphatidylinositol 4,5-bisphosphate); TCA, trichloroacetic acid. 
defined as a neuroepithelioma (McKeon et al., 1988). The results indicate that SK-N-MC cells express at least four distinct receptors linked to PPI hydrolysis, one of which is the muscarinic $M_{1}$ subtype, previously identified on a number of other neurotumor cell lines. In addition, a $\mathrm{P}_{2}$ nucleotide receptor is functionally linked, as well as two other receptor subtypes not yet established to operate through enhanced PPI turnover in neural tissues, i.e., an $\alpha_{1 \mathrm{~A}}$-adrenergic receptor and an endothelin (ET) receptor subtype selectively activated by ET-1 and ET-2.

\section{MATERIALS AND METHODS}

SK-N-MC cells (passage no. 42) were obtained from American Type Culture Collection (Rockville, MD, U.S.A.), myo- $\left[2-{ }^{3} \mathrm{H}\right]$ Inositol $(15 \mathrm{Ci} / \mathrm{mmol})$ was obtained from American Radiolabeled Chemicals (St. Louis, MO, U.S.A.) or Amersham Corp. (Arlington Heights, IL, U.S.A.). The following radiolabeled inositol phosphates [1-D-myo-inositol monophosphate ( $\left.\mathrm{IP}_{1}\right), 1$-D-myo-inositol bisphosphate $\left(\mathrm{IP}_{2}\right)$, 1-D-myo-inositol trisphosphate $\left(\mathrm{IP}_{3}\right)$, and 1-D-myo-inositol tetrakisphosphate $\left.\left(\mathrm{IP}_{4}\right)\right]$ were obtained from New England Nuclear (Boston, MA, U.S.A.): $\left[2-{ }^{3} \mathrm{H}\right] \mathrm{I}(1) \mathrm{P}_{1}(5 \mathrm{Ci} / \mathrm{mmol})$, [2$\left.{ }^{3} \mathrm{H}\right] \mathrm{I}(4) \mathrm{P}_{1}(4.5 \mathrm{Ci} / \mathrm{mmol}),\left[2-{ }^{3} \mathrm{H}\right] \mathrm{I}(1,4) \mathbf{P}_{2}(4.5 \mathrm{Ci} / \mathrm{mmol}),[1-$ $\left.{ }^{3} \mathrm{H}\right] \mathrm{I}(1,4,5) \mathrm{P}_{3}(20 \mathrm{Ci} / \mathrm{mmol}),\left[1-{ }^{3} \mathrm{H}\right] \mathrm{I}(1,3,4) \mathrm{P}_{3}(17 \mathrm{Ci} / \mathrm{mmol})$, and $\left[2-{ }^{3} \mathrm{H}\right] \mathrm{I}(1,3,4,5) \mathrm{P}_{4}(5 \mathrm{Ci} / \mathrm{mmol})$. (-)-Norepinephrine (NE), serotonin, histamine, $\mathrm{Arg}^{8}$-vasopressin, substance $\mathrm{P}$, bombesin, neurotensin, ATP, ADP, GTP, ITP, XTP, UTP, AMP, adenosine, phenylephrine, bethanechol, arecoline, digitonin, and (-)-isoproterenol were obtained from Sigma Chemical Co. (St. Louis, MO, U.S.A.). Chloroethylclonidine, (-)-epinephrine (Epi) bitartrate, clonidine, WB-4101, 5methylurapidil, 6-fluonorepinephrine, prazosin, yohimbine, phentolamine, oxotremorine-M (Oxo-M), adenosine $5^{\prime}-O-(2-$ thiodiphosphate) (ADP $\beta S$ ), and 2-methylthioadenosine $5^{\prime}$. triphosphate (2MeSATP) were purchased from Research Biochemicals, Inc. (Natick, MA, U.S.A.). Ionomycin and adenosine 5 - $O$-(3-thiotriphosphate) (ATP $\gamma$ S) were purchased from CalBiochem (San Diego, CA, U.S.A.). ET-1, ET-2, and ET-3 were obtained from Peninsula Laboratories (Belmont, CA, U.S.A.). Phytic acid was purchased from Aldrich Chemical Co. (Milwaukee, WI, U.S.A.), and a partial hydrolysate was prepared as previously described (Heacock et al., 1990). Tissue culture supplies were obtained from Corning Glass Works (Corning, NY, U.S.A.). Powdered Dulbecco's modified Eagle's medium and fetal bovine serum were purchased from GIBCO (Grand Island, NY, U.S.A.). Dowex-1 (100200 mesh, X8 in the formate form) was obtained from BioRad (Rockville Center, NY, U.S.A.). The pentaacetoxymethyl ester derivative of fura-2 (fura-2/AM) was obtained from Molecular Probes (Eugene, OR, U.S.A.). Pirenzepine and 11[[2-[(diethylamino)methyl]-1-piperidinyl]-acetyl]-5,11-dihydro-6 $H$-pyrido[2,3b][1,4]benzodiazepin-6-one (AF-DX 116) were obtained from Boehringer-Ingelheim (Ridgefield, CT, U.S.A.).

\section{Cell culture conditions}

Human SK-N-MC neuroepithelioma cells (passage numbers 43-67; Biedler et al., 1973) were grown in tissue culture flasks $\left(75 \mathrm{~cm}^{2} / 250 \mathrm{ml}\right)$ in $20 \mathrm{ml}$ of Dulbecco's modified Eagle's medium supplemented with $10 \%$ (by volume) fetal bovine serum (medium I). Cells were grown for 5-14 days at $37^{\circ} \mathrm{C}$ in an atmosphere consisting of $10 \% \mathrm{CO}_{2}$ and $90 \%$ hu- midified air. Subculture was achieved by aspirating medium $I$ and isolating the cells following incubation in a modified Puck's $\mathrm{D}_{1}$ solution containing $0.5 \mathrm{~m} M$ EDTA and $0.05 \%$ trypsin (medium II; Honegger and Richelson, 1976). (Although the use of trypsin was essential for efficient detachment of the neuroepithelioma cells, the possibility of its adverse effect on receptor-effector coupling events, while unlikely, cannot be excluded.) After centrifugation of the cell suspension for $1 \mathrm{~min}$ at $300 \mathrm{~g}$, the supernatant was removed and cells resuspended in $10 \mathrm{ml}$ of medium I which was then inoculated into flasks (one confluent flask into five to 10 flasks) on day 0 . The culture medium was changed on day 4 and on alternate days thereafter by the addition of $10 \mathrm{ml}$ of fresh medium I and removal of $10 \mathrm{ml}$ of medium.

\section{Measurement of PPI turnover}

SK-N-MC cells were allowed to prelabel for 2-3 days in Dulbecco's modified Eagle's medium $/ 10 \%$ fetal bovine serum containing $\left.2.5-10 \mu \mathrm{Ci} / \mathrm{ml} \mathrm{[}{ }^{3} \mathrm{H}\right]$ inositol. In preliminary experiments, it was determined that a $24-\mathrm{h}$ labeling period was sufficient for the lipids to attain an isotopic equilibrium of labeling. Cells were detached in medium II and washed twice in buffer A $\left(142 \mathrm{~m} M \mathrm{NaCl}, 5.6 \mathrm{~m} M \mathrm{KCl}, 2.2 \mathrm{~m} M \mathrm{CaCl}_{2}\right.$, $3.6 \mathrm{~m} M \mathrm{NaHCO}_{3}, 1 \mathrm{mM} \mathrm{MgCl}_{2}, 5.6 \mathrm{~m} M$ D-glucose, and 30 $\mathrm{m} M$ sodium HEPES buffer, $\mathrm{pH}$ 7.4). Cells were then resuspended in buffer $\mathrm{A}$ and incubated at $37^{\circ} \mathrm{C}$ in the presence of agonists and/or antagonists (final volume $0.5 \mathrm{ml}$ ). The accumulation of ${ }^{3} \mathrm{H}$-inositol phosphates was then monitored in the presence of $\mathrm{Li}^{+}$, as previously described (Thompson and Fisher, 1990). Unless stated otherwise, a 30-min incubation period was routinely employed. In some experiments, the individual inositol phosphate isomers were separated by HPLC and quantitated as previously described (Fisher et al., 1990). Reactions were terminated by the addition of $2 \mathrm{ml}$ of ice-cold $0.9 \% \mathrm{NaCl}$; the cells were centrifuged for $3 \mathrm{~min}$ at $500 \mathrm{~g}$ and the supernatants removed by aspiration. To the cell pellets was added $0.5 \mathrm{ml}$ of $5 \%$ trichloroacetic acid (TCA), and the tubes were left on ice for $20 \mathrm{~min}$ to allow precipitation of protein. Inclusion of $200 \mu \mathrm{g}$ of phytate hydrolysate at this stage optimized the recoveries of $\mathrm{IP}_{3}$ and $\mathrm{IP}_{4}$ (Horstman et al., 1988). Inositol phosphate isomers present in neutralized TCA extracts were then separated on a Whatman Partisil 10 SAX column. Radioactivity was monitored either on-line by means of a Beckman System Gold 171 Flow Counter, with an efficiency of 20-30\% with Beckman Ready Flow III scintillation fluid (ratio of scintillant/eluate, 4:1) or, alternatively, fractions were collected and radioactivity determined directly by liquid scintillation counting. Inositol phosphate isomers were identified from the elution times of authentic radiolabeled standards, i.e., $\mathrm{I}(1) \mathrm{P}_{1}, \mathrm{I}(4) \mathrm{P}_{1}, \mathrm{I}(1,4) \mathrm{P}_{2}, \mathrm{I}(1,3,4) \mathrm{P}_{3}$, $\mathrm{I}(1,4,5) \mathrm{P}_{3}$, and $\mathrm{I}(1,3,4,5) \mathrm{P}_{4}$.

\section{Measurement of fura-2 efflux from SK-N-MC cells}

SK-N-MC cells were loaded with $1 \mu M$ fura-2/AM for 15 min at $37^{\circ} \mathrm{C}$ under conditions previously described for SKN-SH cells (Fisher et al., 1989). The SK-N-MC cells were then washed twice with buffer $A$ to remove excess fura-2/ AM and resuspended in fresh buffer A. Aliquots of fura-2loaded SK-N-MC cells were then allowed to incubate at $37^{\circ} \mathrm{C}$ for $30 \mathrm{~min}$ in the presence or absence of $1 \mathrm{mMATP}$. At the end of this time interval, cells were centrifuged at $300 \mathrm{~g}$ for 5 min and supernatants collected. Fluorescence of supernatants $\left(\lambda_{\text {excitation }}=340 \mathrm{~nm}, \lambda_{\text {emission }}=490 \mathrm{~nm}\right)$ was monitored in a Shimadzu spectrophotofluorometer. The release of fura2 was calculated as a percentage of dye initially present (ob- 
tained from supernatant fluorescence following the addition of $10 \mu M$ digitonin). The concentration of free $\mathrm{Ca}^{2+}$ in buffer solutions was determined directly by fura-2 (free acid) fluorescence (Fisher et al., 1989). Protein was determined by the method of Geiger and Bessman (1972).

\section{Data analysis}

Values quoted are means \pm SEM for the number of separate experiments performed. Student's two-tailed $t$ tests were used to evaluate the statistical differences of the means of unpaired sets of data. The release of inositol phosphates is expressed as a percentage of control and is calculated from the equation:

$$
\text { inositol phosphate release }=\frac{A-Z}{B-Z} \times 100
$$

where $A$ and $B$ are the values obtained for inositol phosphate release in the presence of the agonist $(A)$ or absence of the agonist $(B)$ after a 30-min incubation period, and $Z$ is inositol phosphate release obtained at zero time. Calculation of antagonist inhibition constants were derived from the equation: $K_{\mathrm{i}}=\mathrm{IC}_{50} /\left(1+[A] / \mathrm{EC}_{50}\right)$, where $\mathrm{IC}_{50}$ is the concentration of antagonist required for a $50 \%$ inhibition, $[A]$ is the agonist concentration, and $\mathrm{EC}_{50}$ is the concentration of agonist required for half-maximal stimulation of PPI turnover (Cheng and Prusoff, 1973). The $K_{\mathrm{i}}$ values so obtained are apparent in that two assumptions are made: (a) a competitive interaction exists between the agonist and antagonist, and (b) there is an absence of any substantial receptor reserve for PPI turnover. In all situations examined to date, the second assumption holds true (Fisher and Agranoff, 1987). Dose-response and dose-inhibition curves were analyzed by the GraphPad InPlot curve-fitting program.

\section{RESULTS}

\section{Biochemical characteristics of ligand-activated PPI hydrolysis in SK-N-MC cells}

Of 11 ligands tested, the addition of optimal concentrations of four, i.e., NE, Oxo-M, ET-1, and ATP, each elicited an increased release of ${ }^{3} \mathrm{H}$-inositol phosphates from SK-N-MC cells that had been allowed to label to isotopic equilibrium with $\left[{ }^{3} \mathrm{H}\right]$ inositol (Table 1). Stimulation of PPI turnover by these agonists, although variable in magnitude between experiments, was observed consistently. In contrast, the addition of serotonin, histamine, quisqualate, vasopressin, substance $\mathbf{P}$, bombesin, or neurotensin had little or no effect on inositol phosphate release. Activation of PPI turnover by each of the four active ligands required the addition of $\mathrm{Ca}^{2+}$ for a full effect. Thus, when $\mathrm{Ca}^{2+}$ was omitted from the incubation medium (free $\mathrm{Ca}^{2+}$ $\sim 1 \mu M$ ), the stimulation of ${ }^{3} \mathrm{H}$-inositol phosphate release elicited by the addition of NE, Oxo-M, ET-1, and ATP was inhibited by $36 \pm 9 \%, 56 \pm 5 \%, 57 \pm 6 \%$, and $57 \pm 12 \%$, respectively $(n=3)$. When $1 \mathrm{~m} M$ EGTA was added, stimulated PPI turnover was inhibited further (data not shown). The addition of $10 \mu M$ ionomycin also increased the release of inositol phosphates to $351 \pm 83 \%$ of control $(n=4)$.

Both basal and agonist-stimulated inositol phosphate release proceeded approximately linearly with time
TABLE 1. Ligand-stimulated ${ }^{3} H$-inositol phosphate formation in $S K-N-M C$ cells

\begin{tabular}{lcr}
\hline \multicolumn{1}{c}{ Ligand } & Concentration & $\begin{array}{c}\text { Release of inositol } \\
\text { phosphates } \\
(\% \text { of control })\end{array}$ \\
\hline NE & $1 \mathrm{mM}$ & $723 \pm 49(\mathrm{n}=48)$ \\
Oxo-M & $1 \mathrm{mM}$ & $879 \pm 88(\mathrm{n}=30)$ \\
ET-1 & $0.5 \mu M$ & $678 \pm 61(\mathrm{n}=19)$ \\
ATP & $1 \mathrm{mM}$ & $401 \pm 34(\mathrm{n}=20)$ \\
Serotonin & $1 \mathrm{mM}$ & $94 \pm 13(\mathrm{n}=4)$ \\
Histamine & $1 \mathrm{mM}$ & $128 \pm 21(\mathrm{n}=4)$ \\
Quisqualate & $0.3 \mathrm{mM}$ & $97 \pm 10(\mathrm{n}=3)$ \\
Substance P & $1 \mu M$ & $112 \pm 20(\mathrm{n}=3)$ \\
Vasopressin & $1 \mu M$ & $118 \pm 7(\mathrm{n}=3)$ \\
Bombesin & $1 \mu M$ & $92 \pm 9(\mathrm{n}=3)$ \\
Neurotensin & $50 \mu M$ & $114 \pm 11(\mathrm{n}=3)$ \\
\hline
\end{tabular}

Prelabeled SK-N-MC cells $(\sim 1 \mathrm{mg}$ of protein) were incubated for $30 \mathrm{~min}$ at $37^{\circ}$ with the ligands as indicated. Reactions were terminated by the addition of an equal volume of $20 \% \mathrm{TCA}$, and labeled inositol phosphates present in the neutralized TCA extracts were quantitated by anion-exchange chromatography. Results are expressed as release of inositol phosphates relative to control incubations for the number of separate experiments indicated.

over a $60-\mathrm{min}$ period with no evidence of receptor desensitization (Fig. 1). Unless stated otherwise, a 30min incubation time was chosen routinely. Although the release of a total inositol phosphate fraction was monitored routinely, in some experiments the individual inositol phosphate isomers present were also identified by HPLC (Fig. 2). All four agonists elicited an increased release of $\left[{ }^{3} \mathrm{H}\right] \mathrm{I}(1 / 3) \mathrm{P}_{1}$ (an enantiomeric pair), $\left[{ }^{3} \mathrm{H}\right] \mathrm{I}(4) \mathrm{P}_{1},\left[{ }^{3} \mathrm{H}\right] \mathrm{IP} \mathrm{P}_{2},\left[{ }^{3} \mathrm{H}\right] \mathrm{I}(1,3,4) \mathrm{P}_{3}$, and $\left[{ }^{3} \mathrm{H}\right] \mathrm{IP} \mathrm{P}_{4}$, the largest increases (on a fold basis) being observed for $\mathrm{I}(1 / 3) \mathrm{P}_{1}, \mathrm{I}(4) \mathrm{P}_{1}, \mathrm{I}(1,3,4) \mathrm{P}_{3}$, and $\mathrm{IP}_{4}$ (Table 2). An increased release of labeled $\mathrm{I}(1,4,5) \mathrm{P}_{3}$ was observed frequently, but not consistently, at the 30-min time point selected.

\section{Pharmacological identification of receptor subtypes coupled to PPI turnover}

Adrenergic. The addition of either NE or Epi to SK$\mathrm{N}$-MC cells resulted in a concentration-dependent increase in ${ }^{3} \mathrm{H}$-inositol phosphate release (Fig. 3). The $\mathrm{EC}_{50}$ for $\mathrm{NE}$ was $6.3 \pm 0.7 \mu \mathrm{M}(\mathrm{n}=3)$, whereas that for Epi was $2 \mu M(\mathrm{n}=2)$. As previously noted for brain slices (Minneman and Johnson, 1984), Epi was found consistently to be a more efficacious agonist than NE. Other adrenergic agonists, such as 6-fluonorepinephrine and phenylephrine (selective for the $\alpha_{1}$ subtype), were partial agonists for stimulated PPI turnover. Neither the addition of the $\alpha_{2}$-selective agonist clonidine nor the $\beta$-selective agonist isoproterenol stimulated PPI hydrolysis (Table 3). Further evidence for the involvement of an $\alpha_{1}$-receptor subtype was obtained from antagonist studies. Addition of phentolamine, a nonselective $\alpha$ antagonist, blocked NE-stimulated PPI turnover with a $K_{\mathrm{i}}$ of $11 \mathrm{nM}$. In contrast, the $\alpha_{2}$-selective antagonist yohimbine inhibited with a 38 -fold lower potency $\left(K_{\mathrm{i}}=416 \mathrm{n} M\right.$; Fig. 4). Because at least 


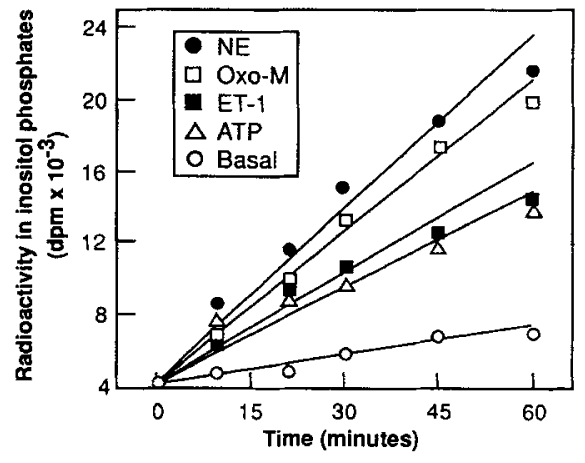

FIG. 1. Time course of basal and ligand-stimulated ${ }^{3} \mathrm{H}$-inositol phosphate formation. Prelabeled SK-N-MC cells ( $\sim 1 \mathrm{mg}$ of protein) were incubated in either the absence (basal) or presence of NE (1 $\mathrm{mM})$, OXo-M (1 mM), ET-1 $(0.5 \mu M)$, or ATP $(1 \mathrm{mM})$ for the times indicated at $37^{\circ} \mathrm{C}$. Reactions were terminated by the addition of an equal volume of $20 \%$ TCA, and a total inositol phosphate fraction present in neutralized extracts was quantitated by anion-exchange chromatography. Values shown are means of triplicate determinations (SEM $<10 \%$ of means).

two $\alpha_{1}$-receptor subtypes $\left(\alpha_{1 \mathrm{~A}}\right.$ and $\left.\alpha_{1 \mathrm{~B}}\right)$ can now be differentiated on the basis of antagonist potency, we evaluated the abilities of WB-4101, prazosin, and 5methylurapidil to block NE-stimulated inositol phosphate formation. All three antagonists were potent inhibitors. 5-Methylurapidil $\left(K_{\mathrm{i}}=2.2 \mathrm{nM}\right)$, which exhibits most selectivity for the $\alpha_{1 \mathrm{~A}}$ subtype (Hanft and Gross, 1989), was almost as effective as either prazosin $\left(K_{\mathrm{i}}=0.6 \mathrm{n} M\right)$ or WB-4101 $\left(K_{\mathrm{i}}=0.9 \mathrm{n} M\right)$ in inhibiting the PPI response (Fig. 5). The Hill coefficients for inhibition were close to $1(0.84-0.98)$, indicating that these antagonists bound predominantly to a single form of the receptor. The $\alpha_{1 \mathrm{~A}}$ and $\alpha_{1 \mathrm{~B}}$ subtypes have also been differentiated on the basis of their susceptibilities to the alkylating agent chloroethylclonidine, the $\alpha_{1 \mathrm{~B}}$ subtype exhibiting a greater sensitivity (Han et al., 1990). Pretreatment of SK-N-MC cells with $50 \mu M$
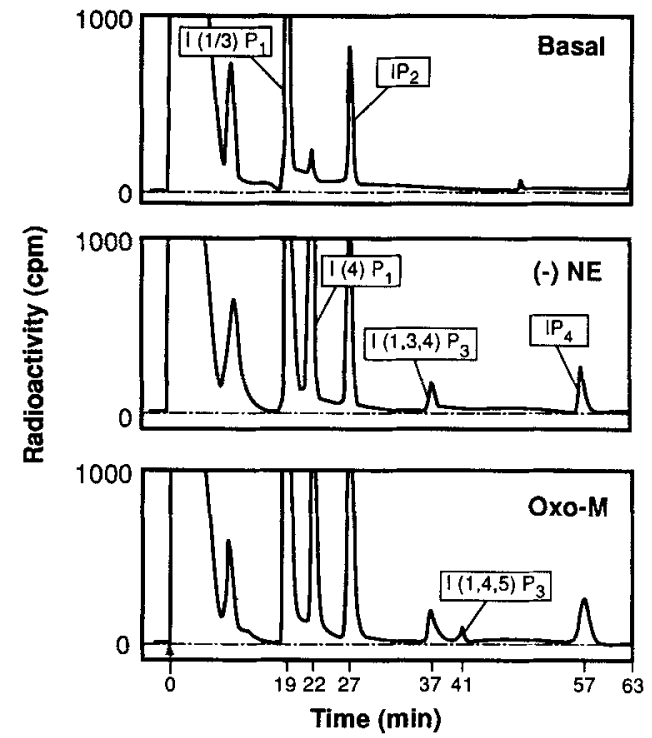

FIG. 2. HPLC separation of inositol phosphate isomers. Prelabeled SK-N-MC cells ( $\sim 5 \mathrm{mg}$ of protein) were incubated for $30 \mathrm{~min}$ at $37^{\circ} \mathrm{C}$ in either the absence (basal) or presence of NE $(1 \mathrm{mM})$ or Oxo-M (1 mM). Reactions were terminated by the addition of icecold $0.9 \% \mathrm{NaCl}$; cells were centrifuged and supernatants removed by aspiration. Inositol phosphates were extracted from the cell pellets following the addition of 5\% TCA (and $200 \mu \mathrm{g}$ of phytate hydrolysate), and isomers present in the neutralized TCA extracts were separated by HPLC. Elution patterns shown are from one of three experiments that gave similar results. The isomer profiles obtained for ET-1 and ATP were qualitatively similar to those of NE and Oxo-M. Note that increases in $1(1,4,5) P_{3}$ were not observed consistently, whereas increases in $I(1 / 3) P_{1}, I(4) P_{1}, I P_{2}, I(1,3,4) P_{3}$, and $\mathbb{P}_{\mathbf{4}}$ were always detected.

chloroethylclonidine for 30 min resulted in a modest (36\%) inhibition of NE-stimulated ${ }^{3} \mathrm{H}$-inositol phosphate release in SK-N-MC cells (Table 4). Although neither ET-1- nor ATP-stimulated PPI turnover was influenced by chloroethylclonidine pretreatment, there was a $21 \%$ reduction of Oxo-M-stimulated inositol

TABLE 2. HPLC separation and quantitation of inositol phosphate isomers formed in $S K-N-M C$ cells

\begin{tabular}{lccccc}
\hline & \multicolumn{5}{c}{ Radioactivity (cpm) } \\
\cline { 2 - 6 } & Basal & NE & Oxo-M & ET-1 & ATP \\
\hline $\mathrm{I}(1 / 3) \mathrm{P}_{1}$ & $6,288 \pm 241$ & $23,042 \pm 689$ & $46,715 \pm 1069$ & $21,951 \pm 572$ & $14,938 \pm 444$ \\
$\mathrm{I}(4) \mathrm{P}_{1}$ & $314 \pm 314$ & $6,489 \pm 506$ & $15,898 \pm 1178$ & $5,835 \pm 336$ & $2,806 \pm 212$ \\
$\mathrm{IP}_{2}$ & $3,175 \pm 410$ & $6,413 \pm 443$ & $14,832 \pm 1090$ & $5,070 \pm 314$ & $4,920 \pm 384$ \\
$\mathrm{I}(1,3,4) \mathrm{P}_{3}$ & $298 \pm 54$ & $1,088 \pm 16$ & $1,977 \pm 79$ & $709 \pm 22$ & $461 \pm 20$ \\
$\mathrm{I}(1,4,5) \mathrm{P}_{3}$ & $517 \pm 44$ & $751 \pm 42$ & $1,120 \pm 36$ & $645 \pm 62^{a}$ & $526 \pm 66^{a}$ \\
$\mathrm{IP}_{4}$ & $693 \pm 102$ & $2,132 \pm 86$ & $3,822 \pm 180$ & $1,513 \pm 49$ & $1,247 \pm 33$ \\
\hline
\end{tabular}

SK-N-MC cells were prelabeled with $\left[{ }^{3} \mathrm{H}\right]$ inositol $(10 \mu \mathrm{Ci} / \mathrm{ml})$ for 3 days. Cells $(\sim 5 \mathrm{mg}$ of protein) were incubated with either NE $(1 \mathrm{~m} M)$, Oxo-M $(1 \mathrm{~m} M)$, ET-1 $(0.5 \mu M)$, or ATP $(1 \mathrm{mM})$ for $30 \mathrm{~min}$. Reactions were terminated by the addition of ice-cold $0.9 \% \mathrm{NaCl}$; cells were centrifuged and supernatants removed by aspiration. Inositol phosphates were extracted from the cell pellets following the addition of 5\% TCA (and $200 \mu \mathrm{g}$ of phytate hydrolysate), and isomers present in the neutralized TCA exctracts were separated by HPLC. Results shown are means \pm SEM for triplicate determinations from one of three experiments that gave similar results. For all four agonists, the release of individual inositol phosphate isomers was statistically different from that obtained for control incubations $(p<0.05)$, with the exception of those instances marked with an $a$. 


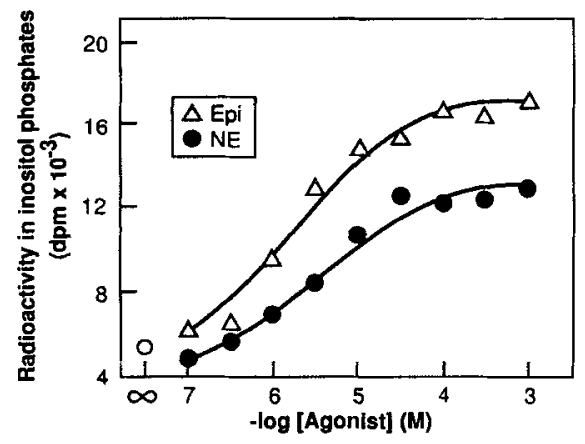

FIG. 3. Concentration dependence of NE- and Epi-stimulated inositol phosphate formation. SK-N-MC cells were incubated in either the absence $(O$, basal) or presence of NE or Epi at the indicated concentrations for $30 \mathrm{~min}$ at $37^{\circ} \mathrm{C}$. Reactions were terminated and inositol phosphates quantitated as described in the legend to Fig. 1. Values shown are means of triplicate determinations (SEM $<5 \%$ of mean). The calculated $\mathrm{EC}_{50}$ values were 2 and $4 \mu \mathrm{M}$ for Epi and $\mathrm{NE}$, respectively. The corresponding Hill coefficients were 0.99 and 1.11 , respectively.

phosphate formation, indicating that the effects of alkylation may not be restricted solely to the adrenergic receptor in this cell line.

Muscarinic cholinergic. Addition of Oxo-M resulted in a concentration-dependent increase in inositol phosphate release with an $\mathrm{EC}_{50}$ value of $20 \pm 3 \mu M$ (n =4). Bethanechol $(10 \mathrm{mM})$ and arecoline $(1 \mathrm{mM})$ were partial agonists $(276 \pm 80 \%$ and $202 \pm 62 \%$ of control, respectively; $n=3$ ). Pirenzepine, an $M_{1}$-selective antagonist, potently inhibited Oxo-M-stimulated PPI turnover $\left(K_{\mathrm{i}}=35 \mathrm{n} M\right)$. In contrast, AF-DX 116 , an antagonist selective for $\mathrm{M}_{2}$ receptors, inhibited with a 30-fold lower affinity $\left(K_{\mathrm{i}}=1.04 \mu M\right.$; Fig. 6).
$E T$. Of the three ETs tested, ET-1 and ET-2 were markedly more effective activators of PPI hydrolysis in SK-N-MC cells than ET-3. Thus, at a concentration of $0.5 \mu M$, addition of ET-1 increased the release of ${ }^{3} \mathrm{H}$-inositol phosphates to $678 \pm 61 \%$ of control (Table 1), whereas the corresponding values obtained for ET2 and ET-3 were $621 \pm 78 \%(\mathrm{n}=6)$ and $154 \pm 15(\mathrm{n}$ $=4$ ), respectively. The $\mathrm{EC}_{50}$ values obtained for ET-1 and ET-2 were similar ( $\sim 10 \mathrm{nM}$; Fig. 7). When both ET-1 and ET-2 were present in the incubations, no further increase in inositol phosphate release was observed compared with that obtained in the presence of either alone, indicating that both ligands interact with a common receptor site (Fig. 8). Inclusion of $0.5 \mu M$ ET-3 did not reduce the effectiveness with which either ET-1 or ET-2 stimulated PPI hydrolysis, indicating that at this concentration ET-3 does not behave as a competitive partial agonist.

Nucleotide. The addition of ATP resulted in a dosedependent increase in ${ }^{3} \mathrm{H}$-inositol phosphate release with an $\mathrm{EC}_{50}$ value of $\sim 100 \mu M$. 2MeSATP, a putative $P_{2 y}$ purinergic agonist, also enhanced PPI turnover with a potency similar to that obtained for ATP (Fig. 9). ATP $\gamma \mathrm{S}, \mathrm{ADP}$, and ADP $\beta$ S were also effective (Table 5). A combination of $1 \mathrm{~m} M$ ATP plus $1 \mathrm{~m} M$ ADP did not result in a stimulation of PPI turnover greater than that elicited by ATP alone. Other purine nucleotides, such as GTP, ITP, and XTP, were able to promote PPI turnover, as was the pyrimidine UTP. AMP was only marginally effective, whereas adenosine was inactive, thereby excluding the involvement of a $P_{1}$ purinoceptor. The addition of ATP (but not other purine nucleotides) can induce a generalized increase in permeability of cell plasma membranes due to the formation of $\mathrm{ATP}^{4-}$ (Cockcroft and Gomperts, 1979;

TABLE 3. Differential effects of adrenergic agonists on PPI turnover in $S K-N-M C$ cells

\begin{tabular}{lcrr}
\hline & & \multicolumn{2}{c}{ Release of inositol phosphates } \\
\cline { 3 - 4 } \multicolumn{1}{c}{ Ligand } & Concentration & \% of control & $\begin{array}{r}\text { \% of NE } \\
\text { response }\end{array}$ \\
\hline $\mathrm{NE}$ & $1 \mathrm{~m} M$ & $723 \pm 49(48)^{a}$ & $(100)$ \\
Epi & $1 \mathrm{~m} M$ & $1,113 \pm 170(6)$ & $149 \pm 7$ \\
6-Fluonorepinephrine & $0.1 \mathrm{~m} M$ & $478 \pm 192(3)$ & $51 \pm 5$ \\
6-Fluonorepinephrine & $1 \mathrm{~m} M$ & $459 \pm 78(4)$ & $38 \pm 6$ \\
Phenylephrine & $0.1 \mathrm{~m} M$ & $339 \pm 76(5)$ & $33 \pm 6$ \\
Phenylephrine & $1 \mathrm{~m} M$ & $272 \pm 73(5)$ & $27 \pm 4$ \\
Clonidine & $0.1 \mathrm{~m} M$ & $118 \pm 19(3)$ & $4 \pm 4$ \\
Clonidine & $1 \mathrm{~m} M$ & $99 \pm 40(3)$ & $5 \pm 5$ \\
Isoproterenol & $10 \mu M$ & $109 \pm 37(3)$ & $6 \pm 5$ \\
Isoproterenol & $0.1 \mathrm{~m} M$ & $141 \pm 36(3)$ & $10 \pm 7$ \\
\hline
\end{tabular}

SK-N-MC cells $\left(\sim 1 \mathrm{mg}\right.$ of protein) were incubated for $30 \mathrm{~min}$ at $37^{\circ} \mathrm{C}$ in either the absence or presence of the adrenergic ligands indicated. Reactions were terminated and inositol phosphates quantitated as described in the footnote to Table 1. Results are expressed either as release of inositol phosphates relative to control incubations or, alternatively, as the release relative to that obtained for NE in the same experiment. The number of separate experiments performed is indicated in parentheses.

${ }^{a}$ Data taken from Table 1. 


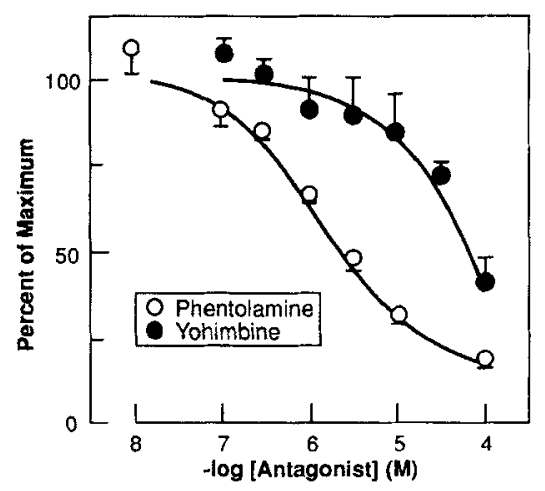

FIG. 4. Phentolamine and yohimbine inhibition of NE-stimulated PPI turnover in SK-N-MC cells. SK-N-MC cells were incubated for $30 \mathrm{~min}$ at $37^{\circ} \mathrm{C}$ in the presence of $1 \mathrm{mM} \mathrm{NE}$ and phentolamine or yohimbine at the concentrations indicated. Results are expressed as percentage of maximum response (obtained with NE alone) as a function of antagonist concentration. Values shown are the means \pm SEM for three to four separate experiments. Neither phentolamine nor yohimbine had any effect on ${ }^{3} \mathrm{H}$-inositol phosphate release when added alone at the highest concentration used. The calculated $K_{i}$ values for phentolamine and yohimbine were 11 and $416 \mathrm{nM}$, respectively. The corresponding Hill coefficients were 0.85 and 0.94 , respectively.

Greenberg et al., 1988). To determine whether SK-NMC cells became leaky in the presence of ATP, the release of fura-2 (from dye-loaded cells) into extracellular fluid was monitored. Over a 30 -min incubation period at $37^{\circ} \mathrm{C}, 53 \pm 7 \%$ of total fura- 2 initially loaded into control cells leaked into the surrounding medium. In the presence of ATP, no further increase in fura-2 leakage occurred $(51 \pm 7 \%, \mathrm{n}=3)$.

\section{DISCUSSION}

The selective ability of four groups of pharmacologically distinct ligands to enhance inositol lipid turnover

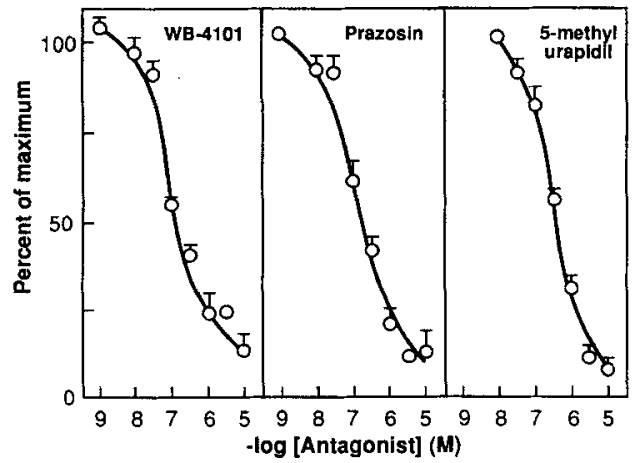

FIG. 5. WB-4101, prazosin, and 5-methylurapidil inhibition of NEstimulated PPI turnover. SK-N-MC cells were incubated for $30 \mathrm{~min}$ at $37^{\circ} \mathrm{C}$ in the presence of $1 \mathrm{mM} \mathrm{NE}$ and the antagonists at the concentrations indicated. Results are expressed as percentage of maximum response (obtained with NE alone) as a function of antagonist concentration. Values shown are the means \pm SEM for four or five separate experiments. Where no error bar is shown, the SEM fell within the symbol. The calculated $K_{1}$ values for WB4101, prazosin, and 5-methylurapidil were 0.6, 0.9, and $2.2 \mathrm{nM}$, respectively. The corresponding Hill coefficients were $0.84,0.96$. and 0.98 , respectively.
TABLE 4. Effect of chloroethylclonidine pretreatment on agonist-stimulated PPI turnover

Release of inositol phosphates (\% of untreated cells)

\begin{tabular}{lcc}
\hline NE & $64 \pm 2^{a}$ & $(4)$ \\
Oxo-M & $79 \pm 1^{a}$ & $(4)$ \\
ET-1 & $102 \pm 6 \quad(3)$ \\
ATP & $118 \pm 14(3)$ \\
\hline
\end{tabular}

SK-N-MC cells were incubated in the presence of $50 \mu M$ chloroethylclonidine or buffer $\mathrm{A}$ for $30 \mathrm{~min}$ at $37^{\circ} \mathrm{C}$. Both groups of cells were then washed twice with buffer $A$ and challenged with either NE (1 $\mathrm{m} M)$, Oxo-M $(1 \mathrm{~m} M)$, ET-1 $(0.5 \mu M)$, or ATP $(1 \mathrm{~m} M)$ for 30 min at $37^{\circ} \mathrm{C}$. Reactions were terminated and inositol phosphates quantitated as described in the footnote to Table 1. Results are expressed as stimulated inositol phosphate release obtained in the chloroethylclonidine-treated cells relative to that observed for control cells. The number of separate experiments performed is indicated in parentheses.

${ }^{a}$ Statistically different from untreated cells $(p<0.02)$.

indicates the presence of multiple PPI-linked receptors on SK-N-MC cells, the characteristics of which are discussed below. Although increases in $\mathrm{I}(1,4,5) \mathrm{P}_{3}$ production were not robust, it appears likely that the addition of each ligand promotes the $\mathrm{Ca}^{2+}$-dependent hydrolysis of polyphosphoinositides, as evident from the stimulated formation of $\mathrm{I}(4) \mathrm{P}_{1}, \mathrm{IP}_{2}, \mathrm{I}(1,3,4) \mathrm{P}_{3}$, and $\mathrm{IP}_{4}$. The minimum contribution of polyphosphoinositides to inositol phosphate production (36-45\%) can be calculated from the sum of radioactivities associated with these inositol phosphate isomers. However, because this calculation ignores $\left[{ }^{3} \mathrm{H}\right] \mathrm{I}(1 / 3) \mathrm{P}_{1}$ formed from sequential dephosphorylations of $\mathrm{I}(1,3,4) \mathrm{P}_{3}$ (Shears, 1989), it is likely to be an underestimate of the true contribution of the polyphosphoinositides. The formation of $\mathrm{IP}_{4}$ and

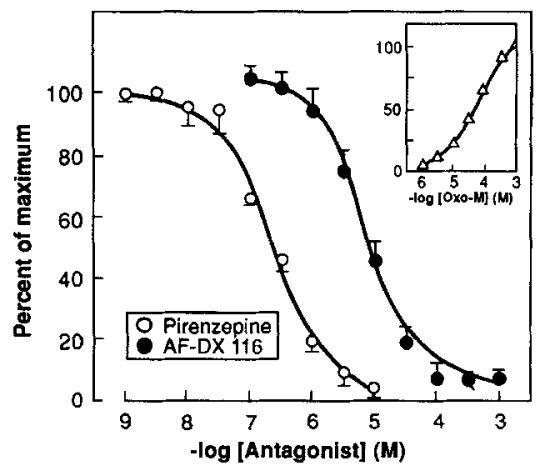

FIG. 6. Pirenzepine and AF-DX 116 inhibition of Oxo-M-stimulated inositol phosphate formation. SK-N-MC cells were incubated for $30 \mathrm{~min}$ at $37^{\circ} \mathrm{C}$ in the presence of $0.1 \mathrm{mM}$ Oxo-M and the antagonists at the concentrations indicated. Results are expressed as percentage of maximum response (obtained with Oxo-M alone) as a function of antagonist concentration. Values shown are means \pm SEM for three separate experiments. The calculated $K_{\mathrm{l}}$ values for pirenzepine and AF-DX 116 were $35 \mathrm{nM}$ and $1.04 \mu M$, respectively. The corresponding Hill coefficients were 1.02 and 1.10 , respectively. Inset: Dose-response curve for Oxo-M. Maximum stimulation of inositol phosphate release was obtained at an agonist concentration of $1 \mathrm{mM}$. 


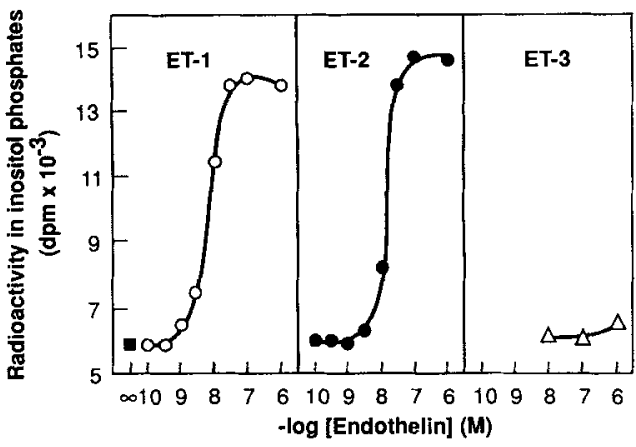

FIG. 7. Differential effects of ETs on PPI turnover. SK-N-MC cells were incubated for $30 \mathrm{~min}$ at $37^{\circ} \mathrm{C}$ in either the absence ( $\square$, basal) or presence of ET-1, ET-2, or ET-3 at the concentrations indicated. Reactions were terminated and inositol phosphates quantitated as described in the legend to Fig. 1. Values shown are means of triplicate determinations (SEM $<5 \%$ of mean) for one of two experiments that gave similar results. The calculated $\mathrm{EC}_{50}$ values for ET-1 and ET-2 were 7 and $15 \mathrm{nM}$, respectively.

$\mathrm{I}(1,3,4) \mathrm{P}_{3}$ is sustained in SK-N-MC cells and, therefore, the $3^{\prime}$-kinase pathway of $\mathrm{I}(1,4,5) \mathrm{P}_{3}$ metabolism appears to operate continuously. As a consequence, $\mathrm{IP}_{1}$ s subsequently formed would be expected to accumulate steadily in the $\mathrm{I}(1 / 3) \mathrm{P}_{1}$ fraction in the presence of $\mathrm{Li}^{+}$. Thus, although the possibility of some direct breakdown of phosphatidylinositol [and hence the formation of $\left.\mathrm{I}(1) \mathrm{P}_{1}\right]$ cannot be discounted, the polyphosphoinositides appear to be a primary source of inositol phosphates in SK-N-MC cells. A similar conclusion as to the lipid origin of stimulated inositol phosphate formation has been drawn recently for parotid glands (Hughes and Putney, 1989), brain slices (Batty and Nahorski, 1989), and SK-N-SH neuroblastoma cells (Fisher et al., 1990). The $\mathrm{Ca}^{2+}$ dependence of stimulated

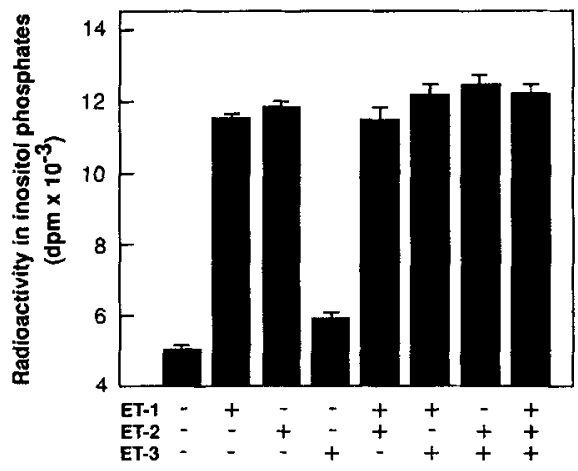

FIG. 8. Lack of additivity between ET-1, ET-2, and ET-3-stimulated inositol phosphate formation. SK-N-MC celis were incubated for $30 \mathrm{~min}$ at $37^{\circ} \mathrm{C}$ in either the absence or presence of $0.5 \mu \mathrm{M}$ concentrations of ET-1, ET-2, and ET-3 as indicated. Reactions were terminated and inositol phosphates quantitated as described in the legend to Fig. 1. Values shown are the means \pm SEM for triplicate determinations obtained in a single experiment. Similar results were obtained in a further four experiments. Note that the stimulations of PPI turnover elicited by ET- 1 and ET-2 are not additive, whereas inclusion of ET-3 does not block the more efficacious ETs, ET-1 and $\mathrm{ET}-2$.

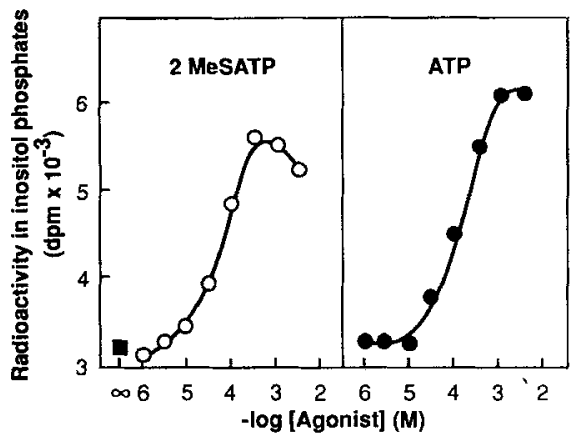

FIG. 9. Both ATP and the putative $P_{2 y}$ agonist 2MeSATP stimulate inositol phosphate formation. SK-N-MC cells were incubated for $30 \mathrm{~min}$ at $37^{\circ} \mathrm{C}$ in either the absence ( $\mathrm{m}$, basal) or presence of either ATP or 2MeSATP at the concentrations indicated. Reactions were terminated and inositol phosphates quantitated as described in the legend to Fig. 1. Values shown are means of triplicate replicates (SEM $<5 \%$ of mean) for one of three experiments (ATP) or two experiments (2MeSATP) that gave similar results. The calculated $\mathrm{EC}_{50}$ values in the experiment shown were 47 and $121 \mu \mathrm{M}$ for 2MeSATP and ATP, respectively.

PPI turnover observed for SK-N-MC cells is similar to that previously reported for SK-N-SH neuroblastoma. In the latter cells, phospholipase $\mathrm{C}$ activity is regulated by changes in intracellular $\mathrm{Ca}^{2+}$, and a continuous influx of $\mathrm{Ca}^{2+}$ is proposed to facilitate PPI hydrolysis (Fisher et al., 1989).

There is now compelling evidence for the involvement of $\alpha_{1}$-adrenergic receptors in stimulated PPI turnover in brain (Brown et al., 1984; Minneman and Johnson, 1984; Schoepp et al., 1984). Similarly, in SK$\mathrm{N}-\mathrm{MC}$ cells, an increased PPI hydrolysis is elicited by the addition of the $\alpha_{1}$ agonist phenylephrine, but not

TABLE 5. Effect of purinergic nucleotides on inositol phosphate formation in $S K-N-M C$ cells

\begin{tabular}{llc}
\hline & \multicolumn{2}{c}{ Release of inositol phosphates } \\
\cline { 2 - 3 } & $\%$ of control & \% of ATP response \\
\hline ATP & $401 \pm 34(20)^{a}$ & $(100)$ \\
ATP $\gamma$ S & $256 \pm 31(3)$ & $71 \pm 3$ \\
2MeSATP & $343 \pm 46(4)$ & $86 \pm 10$ \\
ADP $\beta$ S & $298 \pm 56(3)$ & $68 \pm 10$ \\
ADP & $355 \pm 46(4)$ & $88 \pm 8$ \\
GTP & $292 \pm 59(3)$ & $68 \pm 5$ \\
ITP & $277 \pm 45(3)$ & $65 \pm 1$ \\
XTP & $308 \pm 65(3)$ & $74 \pm 6$ \\
UTP & $296 \pm 57(3)$ & $70 \pm 3$ \\
AMP & $182 \pm 20(5)$ & $6 \pm 3$ \\
Adenosine & $108 \pm 15(5)$ & 6 \\
\hline
\end{tabular}

SK-N-MC cells ( $\sim 1 \mathrm{mg}$ of protein) were incubated for $30 \mathrm{~min}$ at $37^{\circ} \mathrm{C}$ in either the absence or presence of the ligands indicated (all at a $1 \mathrm{~m} M$ concentration). Reactions were terminated and inositol phosphates quantitated as described in the footnote to Table 1 . Results are expressed either as release of inositol phosphates relative to control incubations or, alternatively, the release relative to that obtained for ATP in the same experiment. The number of separate experiments performed is indicated in parentheses.

${ }^{a}$ Data taken from Table 1. 
by the $\alpha_{2}$ agonist clonidine or the $\beta$ agonist isoproterenol. However, two distinct differences can be discerned for adrenergic stimulation of inositol lipid hydrolysis in SK-N-MC cells from that in brain. First, relative to that of NE, the efficacies of the two $\alpha_{1}$-selective agonists phenylephrine and 6-fluonorepinephrine (27-51\%; Table 3) are markedly less than those observed for brain (62-94\%; Johnson and Minneman, 1986; Minneman, 1988). Second, from antagonist studies, the functional coupling of an $\alpha_{1 \mathrm{~A}}$ receptor is indicated for SK-N-MC cells, rather than the $\alpha_{1 \mathrm{~B}}$ subtype previously implicated in cerebral cortex (Minneman, 1988; Michel et al., 1990). The two $\alpha_{1}$ subtypes can be distinguished pharmacologically on the basis of (a) 10- and 70-fold greater affinities of the competitive antagonists WB-4101 and 5-methylurapidil, respectively, for the $\alpha_{1 \mathrm{~A}}$ subtype (KD $\sim 1 \mathrm{n} M$; Minneman, 1988; Hanft and Gross, 1989), and (b) a greater susceptibility of the $\alpha_{1 \mathrm{~B}}$ subtype to irreversible blockade by chloroethylclonidine $\left(\mathrm{IC}_{50} \sim 1\right.$ $\mu M$; Minneman, 1988). In SK-N-MC cells, NE-stimulated PPI turnover is inhibited potently by both WB4101 and 5-methylurapidil $\left(K_{\mathrm{i}}<2.5 \mathrm{n} M\right)$, whereas only a modest inhibition of inositol lipid hydrolysis occurs following preincubation of the cells with a high concentration of chloroethylclonidine. The antagonist profile of NE-stimulated PPI turnover in SK-N-MC cells and its susceptibility to alkylation are very similar to those recently observed for $\alpha_{1 \mathrm{~A}}$ receptors identified on renal cells (Han et al., 1990). The present results, together with those from a recent study with cultured glial cells (Wilson and Minneman, 1990a), indicate that both $\alpha_{1 \mathrm{~A}}$ and $\alpha_{\mathrm{BB}}$ subtypes are linked to PPI hydrolysis in neural tissues. Although it has been suggested that activation of $\alpha_{1 \mathrm{~A}}$ receptors may result in the breakdown of phosphatidylinositol rather than of the polyphosphoinositides (Wilson and Minneman, 1990b), such appears not to be the case for the same receptors on SK-N-MC cells.

From transfection studies, at least three muscarinic receptor subtypes $\left(M_{1}, M_{3}\right.$, and $\left.M_{5}\right)$ are known to couple to PPI turnover (Bonner et al., 1988; Ashkenazi et al., 1989). Only two of these subtypes $\left(M_{1}\right.$ and $\left.M_{3}\right)$ have been demonstrated to be functionally linked in the CNS and neural-related tissues (Fisher and Agranoff, 1987, and references therein; Ellis et al., 1990; Forray and El-Fakahany, 1990). Muscarinic acetylcholine receptors linked to PPI turnover in SK-N-MC cells appear to be predominantly of the $M_{1}$ subtype, because pirenzepine inhibited the response with a $K_{\mathrm{i}}$ of $35 \mathrm{n} M$, a value that is close to its affinity binding constant to $M_{1}$ receptors in neural tissues (Watson et al., 1983) and similar to that obtained for inhibition of PPI turnover in other $\mathrm{M}_{1}$-enriched neural preparations (Gonzales and Crews, 1984; Fisher and Bartus, 1985). AFDX 116, an antagonist selective for $\mathrm{M}_{2}$ receptors, inhibits with a 30-fold lower potency in SK-N-MC cells. In contrast, $\mathrm{M}_{3}$ receptors (such as those on SK-N-SH and $1321 \mathrm{~N} 1$ cells) are inhibited relatively weakly by both pirenzepine and AF-DX 116 (Fisher and Heacock,
1988; Kunysz et al., 1989). The potency with which Oxo-M stimulated inositol phosphate formation in SK$\mathrm{N}-\mathrm{MC}$ cells and the relative efficacies of the partial agonists bethanechol and arecoline are similar to those previously observed for the $\mathrm{M}_{\mathrm{i}}$-muscarinic acetylcholine receptor linked to PPI turnover in brain and in NIE-115 cells (Fisher et al., 1984; Fisher and Snider, 1987).

High-affinity binding sites for the ETs (and their structural homologues, the sarafotoxins) have been identified recently in the CNS (Kloog et al., 1988; Jones et al., 1989). Moreover, the functional coupling of these sites to PPI turnover has been demonstrated for a number of brain regions (Kloog et al., 1989b; MacCumber et al., 1990). In SK-N-MC cells, the addition of ET-1 elicits an increase in PPI turnover comparable in magnitude to that observed in brain. However, a notable difference is the inability of ET-3 either to enhance PPI turnover in SK-N-MC cells by itself or to block the effects of ET-1 and ET-2. In contrast, ET-3 is a full agonist in brain, $\mathrm{C}_{6}$ glioma, and primary neuronal cultures (Crawford et al., 1990; Lin et al., 1990; MacCumber et al., 1990). This result raises the possibility that more than one functionally linked subtype of ET receptor may exist. In keeping with this suggestion, Kloog et al. (1989a) have identified three subtypes of the ET receptor on the basis of radioligand binding data. Whereas both ET-1 and ET-3 readily bind to the E-S $\beta$ and E-S $\gamma$ subtypes (found in cerebellum and caudate, respectively), only ET- 1 binds to the E-S $\alpha$ subtype (found in smooth muscles and aorta). Furthermore, two cDNAs encoding separate ET receptors have recently been cloned and expressed in host cells (Arai et al., 1990; Sakurai et al., 1990). One of the receptors $\left(\mathrm{ET}_{\mathrm{A}}\right)$ shows a high specificity for ET-1, whereas the second $\left(E_{B}\right)$ recognizes ET-1 and ET-3 with equal affinity. Although further characterization is necessary, the profile of agonist selectively obtained for stimulation of PPI turnover in SK-N-MC cells is consistent with the involvement of an ET receptor subtype distinct from those previously described in the CNS.

A fourth receptor linked to PPI turnover in SK-NMC cells is activated by the presence of ATP and other purine nucleotides. Because neither AMP nor adenosine exerted a substantial stimulatory effect on inositol lipid hydrolysis, the receptors involved appear to be of the $\mathrm{P}_{2}$ subtype (Burnstock and Kennedy, 1985). $\mathrm{P}_{2}$ receptors linked to PPI turnover have also been demonstrated in astrocytes (Pearce et al., 1989), pituitary cells (Davidson et al., 1990), and adrenal chromaffin cells (Sasakawa et al., 1989; Allsup and Boarder, 1990). In SK-N-MC cells, all purine nucleotide triphosphates tested were able to promote PPI turnover, indicating a broad agonist specificity. However, given the ability of the pyrimidine UTP to enhance inositol phosphate release in this cell line and in other tissues (Fine et al., 1989; Sasakawa et al., 1989), it may be more appropriate to term the receptor involved a "nucleotidoceptor" (Pfeilschifter, 1990). Of the $\mathbf{P}_{2}$-receptor subtypes 
thus far described, it is the $P_{2 y}$ receptor that has been linked to activation of PPI turnover in nonneural tissues (Martin and Harden, 1989; Allsup and Boarder, 1990 ), based largely upon the potency exhibited by the putative $\mathrm{P}_{2 \mathrm{y}}$-selective agonist 2MeSATP for both binding to the receptor and eliciting a functional response. However, although 2MeSATP and ATP are equally effective enhancers of PPI hydrolysis in SK-N-MC cells, they are also equipotent (Fig. 9). Furthermore, 2MeSATP has been reported to be either a partial agonist (Pfeilschifter, 1990) or devoid of activity (Fine et al., 1989) at $P_{2}$ receptors linked to PPI hydrolysis. These observations raise the possibility that the current definition of $\mathbf{P}_{2}$ subtypes is inadequate to account fully for the observed properties of this class of receptors.

In conclusion, the present results indicate that SK$\mathrm{N}-\mathrm{MC}$ cells possess multiple PPI-linked receptors, two of which $\left(\alpha_{1 \mathrm{~A}}\right.$-adrenergic and ET) have received little previous attention. The availability of this cell line may facilitate future studies of both the characterization and regulation of these receptors.

Acknowledgment: The authors wish to thank Dr. A. M. Heacock for her helpful comments and Ms. Jo Ann Kelsch for preparation of the manuscript. This study was supported by NIMH grant no. MH 42652 .

\section{REFERENCES}

Allsup D. J. and Boarder M. R. (1990) Comparison of $P_{2}$ purinergic receptors of aortic endothelial cells with those of adrenal medulla: evidence for heterogeneity of receptor subtype and of inositol phosphate response. Mol. Pharmacol. 38, 84-91.

Arai H., Hori S., Aramori I., Ohkubo H., and Nakanishi S. (1990) Cloning and expression of a cDNA encoding an endothelin receptor. Nature 348, 730-732.

Ashkenazi A., Ramachandran J., and Capon D. (1989) Acetylcholine analogue stimulates DNA synthesis in brain derived cells via specific muscarinic receptor subtypes. Nature 340, 146-150.

Batty I. H. and Nahorski S. R. (1989) Rapid accumulation and sustained turnover of inositol phosphates in cerebral-cortex slices after muscarinic-receptor stimulation. Biochem. J. 260, 237241.

Biedler J. L., Helson L., and Spengler B. A. (1973) Morphology and growth, tumorigenicity, and cytogenetics of human neuroblastoma cells in continuous culture. Cancer Res. 33, 2643-2652.

Bonner T. I., Young A. C., Brann M. R., and Buckley N. J. (1988) Cloning and expression of the human and rat $\mathrm{m} 5$ muscarinic acetylcholine receptor genes. Neuron 1, 403-410.

Brown E., Kendall D. A., and Nahorski S. R. (1984) Inositol phospholipid hydrolysis in rat cerebral cortical slices. 1. Receptor characterisation. $J$. Neurochem. 42, 1379-1387.

Burnstock G. and Kennedy C. (1985) Is there a basis for distinguishing two types of $\mathrm{P}_{2}$-purinoceptor? Gen. Pharmacol. 16, 433-440.

Cheng Y.-C. and Prusoff W. H. (1973) Relationship between the inhibition constant $\left(K_{i}\right)$ and the concentration of inhibitor which causes 50 percent inhibition $\left(\mathrm{IC}_{50}\right.$ ) of an enzymatic reaction. Biochem. Pharmacol. 22, 3099-3108.

Cockcroft S. and Gomperts B. D. (1979) ATP induces nucleotide permeability in rat mast cells. Nature 279, 541-542.

Crawford M. L. A., Hiley C. R., and Young J. M. (1990) Characteristics of endothelin- 1 and endothelin-3 stimulation of phosphoinositide breakdown differ between regions of guinea-pig and rat brain. Naunyn-Schmiedebergs Arch. Pharmacol. 341, 268271.

Davidson J. S., Wakefield I. K., Sohnius U., van der Merwe P. A., and Millar R. P. (1990) A novel extracellular nucleotide receptor coupled to phosphoinositidase-C in pituitary cells. Endocrinology 126, 80-87.

Ellis J., Huyler J. H., Kemp D. E., and Weiss S. (1990) Muscarinic receptors and second-messenger responses of neurons in primary culture. Brain Res. 511, 234-240.

Fine J., Cole P, and Davidson J. S. (1989) Extracellular nucleotides stimulate receptor-mediated calcium mobilization and inositol phosphate production in human fibroblasts. Biochem. J. 263, 371-376.

Fisher S. K. and Agranoff B. W. (1987) Receptor activation and inositol lipid hydrolysis in neural tissues. $J$. Neurochem. 48,999 1016.

Fisher S. K. and Bartus R. T. (1985) Regional differences in the coupling of muscarinic receptors to inositol phospholipid hydrolysis in guinea pig brain. $J$. Neurochem. 45, 1085-1095.

Fisher S. K. and Heacock A. M. (1988) A putative $M_{3}$ muscarinic cholinergic receptor of high molecular weight couples to phosphoinositide hydrolysis in human SK-N-SH neuroblastoma cells. J. Neurochem. 50, 984-987.

Fisher S. K. and Snider R. M. (1987) Differential receptor occupancy requirements for muscarinic cholinergic stimulation of inositol lipid hydrolysis in brain and in neuroblastomas. Mol. Pharmacol. 32, $81-90$.

Fisher S. K., Figueiredo J. C., and Bartus R. T. (1984) Differential stimulation of inositol phospholipid turnover in brain by analogs of oxotremorine. J. Neurochem. 43, 1171-1179.

Fisher S. K., Domask L. M., and Roland R. M. (1989) Muscarinic receptor regulation of cytoplasmic $\mathrm{Ca}^{2+}$ concentrations in human SK-N-SH neuroblastoma cells: $\mathrm{Ca}^{2+}$ requirements for phospholipase $C$ activation. Mol. Pharmacol. 35, 195-204.

Fisher S. K., Heacock A. M., Seguin E. B., and Agranoff B. W. (1990) Polyphosphoinositides are the major source of inositol phosphates in carbamoylcholine-stimulated SK-N-SH neuroblastoma cells. Mol. Pharmacol. 38, 54-63.

Forray C. and El-Fakahany E. (1990) On the involvement of multiple muscarinic receptor subtypes in the activation of phosphoinositide metabolism in rat cerebral cortex. Mol. Pharmacol. 37, 893-902.

Geiger P. J. and Bessman S. P. (1972) Protein determination by Lowry's method in the presence of sulfhydryl reagents. Anal. Biochem. 49, 467-473.

Gonzalez R. A. and Crews F. T. (1984) Characterization of the cholinergic stimulation of phosphoinositide hydrolysis in rat brain slices. J. Neurosci. 44, 3120-3127.

Greenberg S., Di Virgilio F., Steinberg T. H., and Silverstein S. C. (1988) Extracellular nucleotides mediate $\mathrm{Ca}^{2+}$ fluxes in $\mathrm{J} 774$ macrophages by two distinct mechanisms. J. Biol. Chem. 263, 10337-10343.

Han C., Wilson K. M., and Minneman K. P. (1990) $\alpha_{1}$-Adrenergic receptor subtypes and formation of inositol phosphates in dispersed hepatocytes and renal cells. Mol. Pharmacol. 37, 903910.

Hanft G. and Gross G. (1989) Subclassification of $\alpha_{1}$-adrenoceptor recognition sites by urapidil derivatives and other selective antagonists. Br. J. Pharmacol. 97, 691-700.

Heacock A. M., Seguin E. B., and Agranoff B. W. (1990) Developmental and regional studies of the metabolism of inositol 1,4,5trisphosphate in rat brain. J. Neurochem. 54, 1405-1411.

Honegger P. and Richelson E. (1976) Biochemical differentiation of mechanically dissociated mammalian brain in aggregating cell culture. Brain Res. 109, 335-354.

Horstman D. A., Takemura H., and Putney J. W. Jr. (1988) Formation and metabolism of $\left[{ }^{3} \mathrm{H}\right]$ inositol phosphates in AR42J pancreatoma cells. J. Biol. Chem. 263, 15297-15303.

Hughes A. R. and Putney J. W. Jr. (1989) Source of ${ }^{3} \mathrm{H}$-labeled inositol bis- and monophosphates in agonist-activated rat parotid acinar cells. J. Biol. Chem. 264, 9400-9407.

Johnson R. D. and Minneman K. P. (1986) Characterization of $\alpha_{1-}$ adrenoceptors which increase cyclic AMP accumulation in rat cerebral cortex. Eur. J. Pharmacol. 129, 293-305.

Jones C. R., Hiley C. R., Pelton J. T., and Mohr M. (1989) Auto- 
radiographic visualization of the binding sites for $\left[{ }^{125}\right.$ I] endothelin in rat and human brain. Neurosci. Lett. 97, 276-279.

Kloog Y., Ambar I., Sokolovsky M., Kochva E., Wollberg Z., and Bdolah A. (1988) Sarafotoxin, a novel vasoconstrictor peptide: phosphoinositide hydrolysis in rat heart and brain. Science 242, 268-270.

Kloog Y., Bousso-Mittler D., Bdolah A., and Sokolovsky M. (1989a) Three apparent receptor subtypes for the endothelin/sarafotoxin family. FEBS Lett. 253, 199-202.

Kloog Y., Ambar I., Kochva E., Wollberg Z., Bdolah A., and Sokolovsky M. (1989b) Sarafotoxin receptors mediate phosphoinositide hydrolysis in various rat brain regions. FEBS Lett. 242 , 387-390.

Kunysz E., Michel A. D., Whiting R. L., and Woods K. (1989) The human astrocytoma cell line $1321 \mathrm{~N} 1$ contains $\mathbf{M}_{2}$-glandular type muscarinic receptors linked to phosphoinositide turnover. Br. J. Pharmacol. 96, 271-278.

Lin W.-W., Lee C. Y., and Chuang D.-M. (1990) Comparative studies of phosphoinositide hydrolysis induced by endothelin-related peptides in cultured cerebellar astrocytes, $\mathrm{C}_{6}$-glioma and cerebellar granule cells. Biochem. Biophys. Res. Commun. 168, 512 519.

MacCumber M. W., Ross C. A., and Snyder S. H. (1990) Endothelin in brain: receptors, mitogenesis, and biosynthesis in glial cells. Proc. Natl. Acad. Sci. USA 87, 2359-2363.

Martin M. W. and Harden T. K. (1989) Agonist-induced desensitization of a $\mathrm{P}_{2 \mathrm{y}}$ purinergic receptor-regulated phospholipase $\mathrm{C}$. J. Biol. Chem. 264, 19535-19539.

McKeon C., Thiele C. J., Ross R. A., Kwan M., Triche T. J., Miser J. S., and Israel M. A. (1988) Indistinguishable patterns of protooncogene expression in two distinct but closely related tumors: Ewing's sarcoma and neuroepithelioma. Cancer Res. 48, 43074311.

Michel M. C., Hanft G., and Gross G. (1990) $\alpha_{1 \mathrm{~B}^{-}}$but not $\alpha_{1 \mathrm{~A}}$-adrenoceptors mediate inositol phosphate generation. NaunynSchmiedebergs Arch. Pharmacol. 341, 385-387.

Minneman K. P. (1988) $\alpha_{1}$-Adrenergic receptor subtypes, inositol phosphates, and sources of cell $\mathrm{Ca}^{2+}$. Pharmacol. Rev. 40, 87119.
Minneman K. P. and Johnson R. D. (1984) Characterization of alpha1 adrenergic receptors linked to $\left[{ }^{3} \mathrm{H}\right]$ inositol metabolism in rat cerebral cortex. J. Pharmacol. Exp. Ther. 230, 317-323.

Pearce B., Murphy S., Jeremy J., Morrow C., and Dandona P. (1989) ATP-evoked $\mathrm{Ca}^{2+}$ mobilisation and prostanoid release from astrocytes: $\mathrm{P}_{2}$-purinergic receptors linked to phosphoinositide hydrolysis. J. Neurochem. 52, 971-977.

Pfeilschifter J. (1990) Comparison of extracellular ATP and UTP signalling in rat renal mesangial cells. Biochem. J. 272, 469472.

Sakurai T., Yanagisawa M., Takuwa Y., Miyazaki H., Kimura S., Goto K., and Masaki T. (1990) Cloning of a cDNA encoding a non-isopeptide-selective subtype of the endothelin receptor. $\mathrm{Na}$ ture 348, 732-735.

Sasakawa N., Nakaki T., Yamamoto S., and Kato R. (1989) Stimulation by ATP of inositol trisphosphate accumulation and calcium mobilization in cultured adrenal chromaffin cells. $J$. Neurochem. 52, 441-447.

Schoepp D. D., Knepper S. M., and Rutledge C. O. (1984) Norepinephrine stimulation of phosphoinositide hydrolysis in rat cerebral cortex is associated with the alpha $\mathrm{a}_{1}$-adrenoceptor. $\mathrm{J}$. Neurochem. 43, 1758-1761.

Shears S. B. (1989) Metabolism of the inositol phosphates produced upon receptor activation. Biochem. J. 260, 313-324.

Thompson A. K. and Fisher S. K. (1990) Relationship between agonist-induced muscarinic receptor loss and desensitization of stimulated phosphoinositide turnover in two neuroblastomas: methodological considerations. J. Pharmacol. Exp. Ther. 252, 744-752.

Watson M., Yamamura H. I., and Roeske W. R. (1983) A unique regulatory profile and regional distribution of $\left[{ }^{3} \mathrm{H}\right]$ pirenzepine binding in the rat provide evidence for distinct $\mathrm{M} 1$ and $\mathrm{M} 2$ muscarinic receptor subtypes. Life Sci. 32, 3001-3011.

Wilson K. M. and Minneman K. P. (1990a) Pertussis toxin inhibits norepinephrine-stimulated inositol phosphate formation in primary brain cell cultures. Mol. Pharmacol. 38, 274-281.

Wilson K. M. and Minneman K. P. (1990b) Different pathways of $\left[{ }^{3} \mathrm{H}\right]$ inositol phosphate formation mediated by $\alpha_{1 \mathrm{a}^{-}}$and $\alpha_{1 \mathrm{~b}^{-}}$adrenergic receptors. J. Biol. Chem. 265, 17601-17606. 